\title{
シミュレーション評価
}

特定用途システム

\section{PMSM を用いたキャパシタによる電力回生特性解析}

中河 秀紀* 齋藤 真一坚玉 明信 大橋 俊介 (関西大学大学院)

Electric power regeneration characteristic analysis by the capacitor using PMSM

Hideki Nakagawa*,Shinichi Saito,Akinobu Kodama, Shunsuke Ohashi (Kansai University)

キーワード : PMSM, 電力回生

Keywords : Permanent Magnet Synchronous Motor, Regenerated energy

\section{1. はじめに}

$\mathrm{EV}$ の電気エネルギー蓄積, 供給デバイスとして、電気二重層コ ンデンサ、あるいは二次電池の使用検討が進められている。電気二 重層コンデンサはエネルギー密度が小さいものの、パワー特性に優 れており繰り返し寿命が無限である。また重金属などの環境負荷の 大きい材料を用いていないため、デバイス自体が環境保全性の高い デバイスとなっている(1)。

\section{2. キャパシタによる電力回生特性解析}

\section{1 解析モデル}

図 1 に PMSM を用いた回生部, インバータ部の回路図、表 1 に 仕様を示す。ここでは、PMSM を電力回生モードにし、キャパシタ に電力回生させたときの各特性について述べる。ただし、スイッチ ング素子による損失は考慮していない。また式(1)に PMSM におけ るトルクの演算式を示す。なお解析にはパワーエレクトロニク ス回路シミュレータPSIM を用いた。

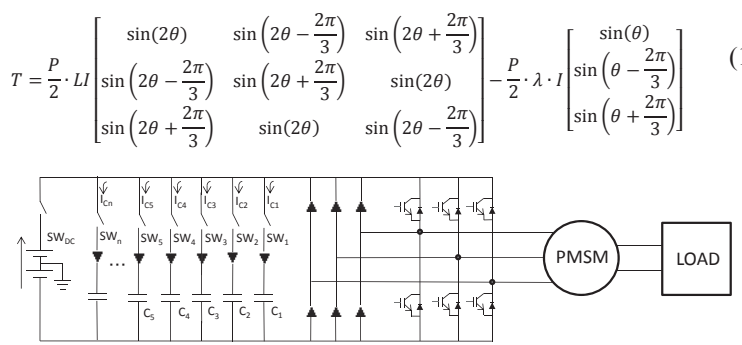

図 1 解析モデル

表 1 解析モデル仕様

\begin{tabular}{|ll|c|}
\hline 抵抗值 & $\mathrm{R}_{\mathrm{s}}$ & $0.8[\Omega]$ \\
\hline 自己インダクタンス & $\mathrm{L}_{\mathrm{a}}$ & $0.375[\mathrm{mH}]$ \\
\hline 慣性モーメント & $\mathrm{J}$ & $83.4\left[\mathrm{gm}^{3}\right]$ \\
\hline 極数 & $\mathrm{P}$ & 8 \\
\hline 機械系時定数 & $\tau_{\text {mech }}$ & $5.0[\mathrm{~s}]$ \\
\hline
\end{tabular}

\section{2 キャパシタ切り替え}

一般的に PMSM が電力回生を行う際、電源部に回生を行う。電 力回生を行う条件は PMSM の電位が電源の電位よりも大きくなく てはならない。そのため PMSM の回転数が減衰し電位が減少して しまうと、回生ができなくなる。今回の解析ではキャパシタの初期 電位がゼロであるものを複数並列に接続し、キャパシタの電位上昇 と共に別のキャパシタに切り替え、常時回生側の電位を下げ電力回 生を行なった。ここでは各々のキャパシタ容量を $C=1.0[\mathrm{~F}]$ 、キャパ
シタのスイッチング条件として、各電位が $V=3.0[\mathrm{~V}]$ に達したときに 切り替えを行った。またスイッチング条件を改良し、回転数が減少 し、 $N_{r e}<100$ 時において $V=1.0[\mathrm{~V}]$ としたときの比較検討を行った。 ただし、電力回生開始時において PMSM の回転数を $N_{r e}=1000[\mathrm{rpm}]$ としている。

\section{3. 解析結果}

図 2 亿電力回生時における回転数, トルク特性、図 3 に回生電力 特性を示寸。図 2 よりスイッチング条件を変えた場合、PMSM の停 止直前まで回生トルクが発生し、またトルク值が増加した。そのた め回転数の減衰速度が向上し、停止時刻を短縮することができた。 しかしスイッチング条件を変更した場合、図 3 より $V=1.0[\mathrm{~V}]$ で切り 替えを行った際に電力值は減少してしまう。これはキャパシタの電 位が下がり電流值が増加し、PMSM の内部抵抗による損失が増加し たためであると考えられる。

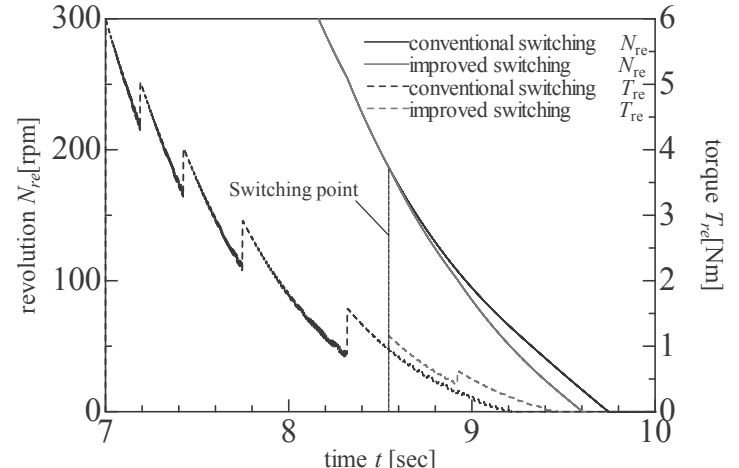

図 2 回転数, $t$ トルク特性

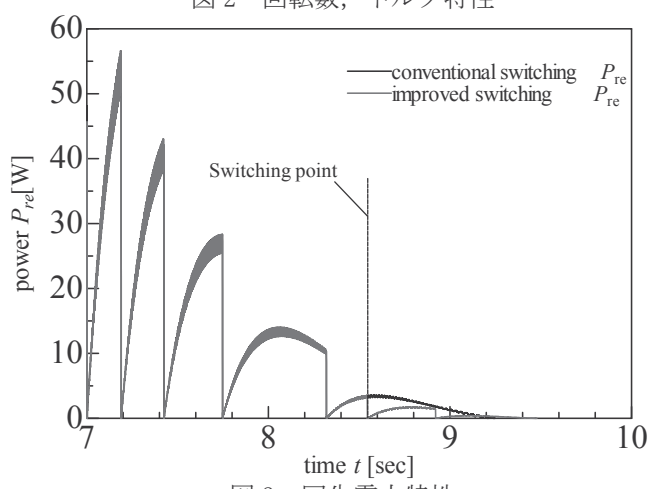

図 3 回生電力特性 文 献

（1）佐藤登：「電気自動車の開発」, 株式会社シーエムシー出版 p.239(2004) 